Baumgarten, K. (1969). Praxis, 58, 519.

Baumgarten, K., Fröhlich, H., Seidl, A., Lim-Rachmat, F, and Sokol, K. (1969). Wiener klinische Wochenschrift 81, 102.

Coutinho, E. M., Bomfim de Sousa F. M., Wilson, K. H., and Landesman, R. (1969). American fournal of Obstetrics and Gynecology, 104, 1053. Flynn, M. J. (1970). Paper presented at the International Symposium on the Highrisk Fetus, Barcelona, October 29-31 1970.

Gamissans, O., Esteban-Altirriba, J., and Maiques, V. (1969). Fournal of Obstetrics and Gynaecology of the British Commonwealth, 76, 656.

Gamissans, O., et al. (1970). Paper presented at the International Symposium on the High-risk Fetus, Barcelona, October 29-31 1970.

Gamissans, O., Esteban-Altirriba, J., and Calaf, J. (1970). To be published. Hendricks, C. H., Cibils, L. A., Pose, S. V., and Eskes, Th. K. A. B. (1961). American fournal of Obstetrics and Gynecology, 82, 1064

Hüter, J. (1969). Therapeutische Umschau, 26, 427.
Landesman, R., Wilson, K. H., Coutinho, E. M., Klima, I. M., and Marcus, R. S. (1971). To be published.

Mainland, D. (1963a). Elementary Medical Statistics, 2nd edn., chapt. 14, p. 287. Philadelphia, Saunders.

Mainland, D. (1963b). Elementary Medical Statistics, 2nd edn., chapt. 14,

Mainland, D. (1963c). Elementary Medical Statistics, 2nd edn., chapt. 12, p. 234. Philadelphia, Saunders.

Mouleón Alegre, F. J., and Brugger Auban, A. J. (1950). Medizinische Klinik (Spanish edition Clinica Medica), 10, 85.

Neumann, H., and Manteuffel, U. (1970). Zentralblatt für Gynäkologie, 92, 1100 .

Wolff, C. H. (1967). Zeitschrift für Geburtshilfe und Gynäkologie, 167, 68 Yo Le Sian, A. (1970). Tijdschrift voor Geneeskunde, 26, 972.

\title{
Problems in the Early Recognition of Congenital Hip Dislocation
}

\author{
GEOFFREY WALKER
}

British Medical fournal, 1971, 3, 147-148

\section{Summary}

Seven cases of infants whose hips were clinically normal at birth, and in whom hip dislocation was later recognized, are reported. In spite of the widespread practice of routine examination of the hips of newborn babies, infants and young children are still presenting with congenital dislocation of the hip. This is probably owing to there being two aetiological types. Every opportunity to re-examine the hips of children under 2 or even 3 years of age must be taken and a high level of suspicion maintained.

\section{Introduction}

Orthopaedic surgeons in children's hospitals and elsewhere continue to see new cases of congenital hip dislocation and dysplasia in spite of the efforts being made in maternity departments and general practice to detect this crippling disorder by clinical examination within the first few days after birth. It now seems reasonably certain that the hips of a newborn infant may be clinically normal at birth, and then develop signs of dislocation or dysplasia during the ensuing months, with the hip seemingly slipping out of joint. This stresses the need for maintaining a high level of suspicion, and of seizing every opportunity to examine the hips of infants and young children. There is also an important medicolegal aspect, as many parents have been led to believe that all hip dislocation is recognizable at birth.

\section{Present Investigation}

Seven children (five girls and two boys) whose hips were examined at birth presented at Queen Mary's Hospital for Children with dysplasia or frank dislocation within the first two years of life. Clinical details are given in Table I. In no case was there any family history of hip disorder. Their ages at presentation were between 2 and 23 months, and in five there

Queen Mary's Hospital for Children, Carshalton, Surrey

GEOFFREY WALKER, F.R.c.S., Consultant Orthopaedic Surgeon was a moderate degree of ligamentous laxity. There were four normal pregnancies and deliveries, one forceps delivery (vertex), one presented as a breech but was successfully turned and delivered normally, and one was delivered as a breech with extended legs. No hip abnormality was detected shortly after birth in six of the babies, and the examiners included a professor of paediatrics, paediatric and obstetric junior staff, general practitioners, and midwives (Table II). In the remaining child a hip click was detected by an orthopaedic surgeon, but the joints were considered to be stable and clinically normal at that time.

A possible hip problem was suspected by the parents in the three eldest children (aged 7, 17, and 23 months), while hip disorders were detected in the four younger (aged 2, 3, 3, and 6 months) at routine medical examinations (Table III). Symptoms included a suspicion of leg length inequality in two children, and a foot which everted in one child.

Limitation of abduction in flexion, which is often absent at birth in complete dislocation, was the main clinical finding in six of the children. This useful but not invariable sign was absent in the oldest child in this series (aged 23 months), whose hips at that time I passed clinically as normal, but in whom an $x$-ray film revealed a dislocation (see Figure).

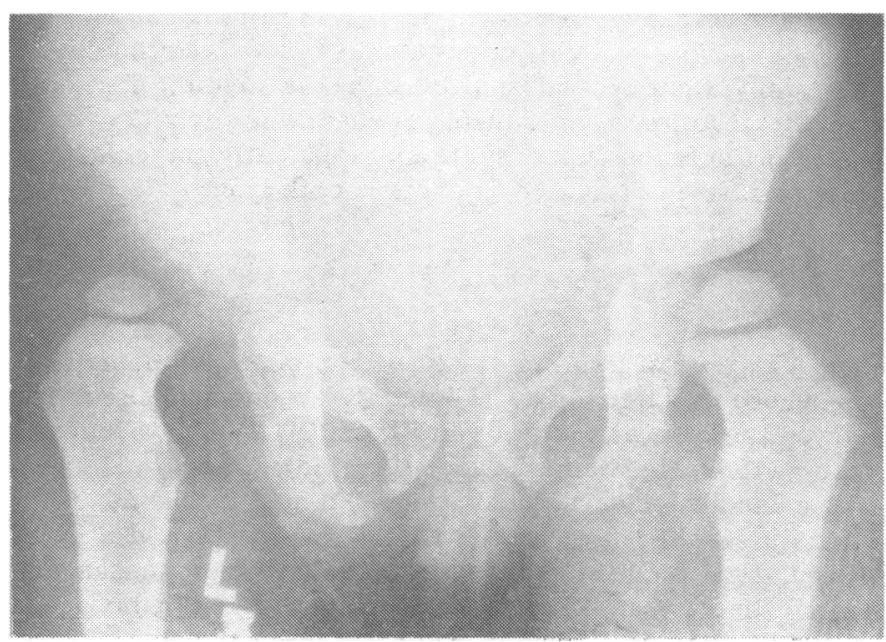

$X$-ray film of the hips of a girl aged 23 months with a left dislocation. This child presented with possible inequality of leg lengths. The hips at birth had been found to be clinically normal, and there was no limitation of abduction in flexion when examined by me at 23 months. 


\begin{tabular}{|c|c|c|c|c|c|c|c|}
\hline \multicolumn{2}{|c|}{$\begin{array}{l}\text { Case } \\
\text { No. }\end{array}$} & \multirow{2}{*}{$\begin{array}{l}\text { Sex } \\
\text { M. }\end{array}$} & \multirow{2}{*}{$\begin{array}{c}\begin{array}{c}\text { Age at Diagnosis } \\
\text { (months) }\end{array} \\
6\end{array}$} & \multirow{3}{*}{$\begin{array}{l}\text { Pregnancy and Delivery } \\
\text { Full-term normal delivery } \\
\begin{array}{l}\text { Breech presentation-turned- } \\
\text { vertex delivery }\end{array}\end{array}$} & \multirow{3}{*}{$\begin{array}{l}\text { Method of Diagnosis } \\
\text { Leg length inequality. Reduced } \\
\text { abduction in flexion } \\
\text { At } 9 \text { days grating click, left } \\
\text { hip clinically stable. At } 3 \\
\text { months reduced abduction in } \\
\text { flexion, and leg length } \\
\text { inequality }\end{array}$} & \multirow{3}{*}{$\begin{array}{l}\text { Ligamentous Laxity } \\
\text { Slight } \\
\text { Moderate }\end{array}$} & \multirow{3}{*}{$\begin{array}{l}\text { X-Ray Appearance } \\
\text { Unilateral acetabula dysplasia- } \\
\text { head half uncovered } \\
\text { Unilateral acetabula dysplasia } \\
\text { and dislocation }\end{array}$} \\
\hline 1 & . & & & & & & \\
\hline 2 & . & F. & 3 & & & & \\
\hline 3 & . & F. & 3 & Full-term normal delivery & $\begin{array}{l}\text { Very slight click at } 2 \text { months. } \\
\text { Reduced abduction in } \\
\text { flexion }\end{array}$ & Nil & $\begin{array}{l}\text { Bilateral acetabula dysplasia. } \\
\text { One hip dislocated the other } \\
\text { uncovered }\end{array}$ \\
\hline 4 & . & F. & 3 & Full-term normal delivery & Reduced abduction in flexion & Moderate & $\begin{array}{l}\text { Bilateral acetabula dysplasia. } \\
\text { One hip dislocated the other } \\
\text { uncovered }\end{array}$ \\
\hline 5 & . & M. & 7 & $\begin{array}{l}\text { 42-week pregnancy, forceps } \\
\text { (vertex) delivery }\end{array}$ & Reduced abduction in flexion & $\begin{array}{l}\text { Moderate and } \\
\text { moderate in both } \\
\text { parents }\end{array}$ & $\begin{array}{l}\text { Unilateral acetabula dysplasia } \\
\text { and dislocation }\end{array}$ \\
\hline 6 & . & F. & 17 & $\begin{array}{l}\text { Full-term. Delivered as } \\
\text { breech with extended legs }\end{array}$ & $\begin{array}{l}\text { Everting foot. Leg length } \\
\text { inequality. Reduced } \\
\text { abduction in flexion }\end{array}$ & Moderate & $\begin{array}{l}\text { Unilateral acetabula dysplasia } \\
\text { and dislocation }\end{array}$ \\
\hline 7 & . & F. & 23 & Full-term normal delivery & $\begin{array}{l}\text { "Bandy" and very slight leg } \\
\text { length inequality. Full } \\
\text { abduction in flexion }\left(90^{\circ}\right. \\
\text { each side). Diagnosed by } \\
x \text {-ray examination (see Fig.) }\end{array}$ & Moderate & $\begin{array}{l}\text { Unilateral acetabula dysplasia } \\
\text { and dislocation }\end{array}$ \\
\hline
\end{tabular}

TABLE III-Details of Recognition of Hip Dysplasia or Dislocation

\begin{tabular}{|c|c|c|c|c|}
\hline Age of Recognition & Presenting Symptoms & Recognized by & & Signs \\
\hline $\begin{array}{l}\text { Three in } 2 \text { nd or } 3 \text { rd month } \\
\begin{array}{lll}\text { Two in } 6 \text { th or } 7 \text { th month } & \ldots \\
\text { One at } 17 \text { months } & \ldots & \ldots \\
\text { One at } 23 \text { months } & \ldots & \ldots\end{array}\end{array}$ & 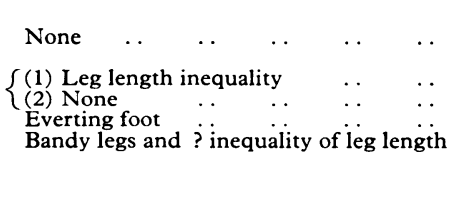 & 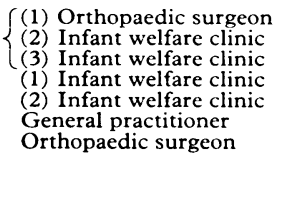 & $\begin{array}{ll}\cdots & \cdots \\
\cdots & \cdots \\
\cdots & \cdots \\
\cdots & \cdots \\
\cdots & \cdots\end{array}$ & $\begin{array}{l}\text { Limitation of abduction } \\
\text { Very slight click and slight loss of abduction } \\
\text { Slight loss of abduction } \\
\text { Loss of abduction and leg length inequality } \\
\text { Loss of abduction } \\
\text { Loss of abduction } \\
\text { Clinically normal apart from suspicion of leg } \\
\text { length inequality-diagnosed by } x \text {-ray } \\
\text { examination }\end{array}$ \\
\hline
\end{tabular}

TABLE II-Status of Hip Examiners at Birth of the Seven Infants

Six infants normal
at birth examined
by $\quad\left\{\begin{array}{l}\text { (1) Senior midwife and general practitioner } \\ \text { (2) Professor of paediatrics and obstetric registrar } \\ \text { (3) Paediatric senior house officer and paediatric clinical } \\ \text { assistant } \\ \text { (4) Obstetric registrar (ex paediatric registrar) and two } \\ \text { midwives. Examined at time of birth and shortly before } \\ \text { discharge from maternity hospital } \\ \text { (5) Obstetric senior house officer } \\ \text { (6) Obstetric senior house officer }\end{array}\right.$

The diagnosis was confirmed in every case by radiography, and, though no special measurements were made, all hips which were dislocated were associated with dysplastic acetabula. In addition, there were two cases of bilateral acetabula dysplasia, with the "good hip" at risk (Table I).

In addition to these seven children I have details of another child with a minimal calcaneus foot deformity whom I examined personally at birth. At that time the hips were stable and abducted in flexion to $90^{\circ}$ on each side. There were no clicks. The family went abroad shortly after the infant's discharge from the maternity department having been advised to seek further orthopaedic supervision, and apparently the child was found to have "a dislocated hip" one month later.

\section{Discussion}

The practice of widespread systematic examination of the hips of newborn children in the United Kingdom and elsewhere followed the pioneer work of von Rosen (1962) in Sweden and Barlow (1962) in Salford, and this information was soon disseminated by publication of a memorandum by the Ministry of Health (1966). However, Owen (fournal of Bone and foint Surgery, 1968) stated that, in spite of intensive propaganda, children aged 1 year or over were still appearing at orthopaedic clinics with congenital dislocation of the hip, and many of these had been born and examined in well-regulated maternity units. He stressed the need for repeated examination of the hips of infants as they develop in order to tighten the net of early diagnosis. A further memorandum from the Department of Health and Social Security (1969) accepted that a proportion of children with congenital dislocation of the hip were being diagnosed late, and that early diagnosis may not always be easy and trouble-free.

By 1970 the possibility of there being two aetiological types of acetabula dysplasia and congenital hip dislocation was being considered among orthopaedic surgeons-a group with joint laxity usually diagnosed early, and those with acetabula dysplasia, probably genetically determined, where diagnosis is likely to be late (Wynne-Davies, 1970). I subscribe to this thesis and believe that an infant's hips may be clinically normal at birth and later proceed to subluxate or dislocate.

Radiography is of importance after the age of 4 to 6 weeks, but I find it of little value during the first few weeks of life. At that time it will confirm a hip which is clinically dislocated, but is unlikely to detect a hip which may later dislocate. I therefore do not believe that all babies' hips, or even all those which click, should have radiographs taken at birth. However, I examine radiographically and clinically at 4 to 6 weeks all those in whom I have felt a click during the first few days of life, or when I have any other cause for suspicion. I also believe that, in addition to ensuring that the hips of all babies are carefully examined at birth, every opportunity must be taken for thorough re-examination during the first two or even three years of life.

I am grateful to Mr. N. Le Page for the illustration, and to the numerous doctors who have supplied clinical details.

\section{References}

Barlow, T. G. (1962). Fournal of Bone and foint Surgery, 44B, 292

Department of Health and Social Security, Central Health Services Council, Standing Medical Advisory Committee (1969). Screening for the Detection of Congenital Dislocation of the Hip in Infants. London, Department of Health and Social Security.

fournal of Bone and foint Surgery, 1968, 50B, 453.

Ministry of Health, Central Health Services Council, Standing Medical Advisory Committee (1966). Screening for Congenital Dislocation of the Hip. London, Ministry of Health.

Rosen, S. von (1962). Fournal of Bone and foint Surgery, 44B, 284.

Wynne-Davies, R. (1970). Fournal of Bone and foint Surgery, 52B, 704. 